\title{
Spatial and temporal dynamics of a plume of phototrophic microorganisms in a meromictic alpine lake using turbidity as a measure of cell density
}

\author{
Konrad Egli, Markus Wiggli, Markus Fritz, Johannes Klug, Joachim Gerss, \\ Reinhard Bachofen*
}

Institute of Plant Biology, University of Zurich, Zollikerstraße 107, 8008 Zurich, Switzerland

\begin{abstract}
Lake Cadagno is a meromictic alpine lake with a dense layer of phototrophic bacteria at about 12 m depth closely below the oxic-anoxic interface. Phototrophic bacteria are known to react by phototaxis and chemotaxis to changes in the environmental factors light, oxygen or hydrogen sulfide. To determine whether this bacterial plume undergoes diel changes in depth and density, a series of absorption and temperature sensors were positioned vertically and horizontally in this layer, allowing changes in local cell concentration and bacterial movement to be followed with high spatial and temporal resolution. The signals from the absorption sensors were proportional to the cell concentrations in the light path. In the lake, the cell concentration in the bacterial layer was highly dynamic and showed oscillations of various frequencies. The width of the bacterial layer and its depth in the water column varied also. Many of these oscillations were a consequence of internal waves and seiches induced by the frequent alpine winds and the morphology of the lake bed. Parallel to fluctuations in cell concentrations, changes in temperature were monitored. This allowed us to distinguish between physically induced displacements of the cells in the water body and the active movement of bacteria due to changes in light conditions and chemical gradients in the water column. Maximum active vertical movements observed during the daytime were about $25 \mathrm{~cm}$. However, diurnal active vertical bacterial movement was not always found throughout the summer season, possibly due to the particular weather situation and to seasonal changes in bacterial community structure.
\end{abstract}

KEY WORDS: Chromatium okenii · Amoebobacter purpureus · Phototrophic bacteria · Turbidity · In vivo $\cdot$ Oscillations $\cdot$ Bacterial movement

Resale or republication not permitted without written consent of the publisher

\section{INTRODUCTION}

Lake Cadagno is a meromictic alpine lake $\left(0.27 \mathrm{~km}^{2}\right)$ situated at an altitude of $1921 \mathrm{~m}$ above sea level in the Piora valley in the southern part of central Switzerland. Its maximal depth is $21 \mathrm{~m}$. The water masses of the lake are stabilized by density differences between the salt-rich water of the monimolimnion, containing mainly sulfate, hydrogen bicarbonate, calcium and magnesium, and the electrolyte-poor oxic mixolimnion (DelDon et al. 2001). The chemocline, separating the oxic epilimnion and the anoxic sulfidogenic hypolimnion, is located at around $12 \mathrm{~m}$ depth during summer. Dense accumulations of various phototrophic sulfur bacteria develop closely below the oxic-anoxic interface. The large Chromatium okenii was earlier described by Düggeli $(1919,1924)$, and recently, Amoebobacter purpureus, Thiocystis sp., and a Chlorobium sp. have also been found in the plume (Eichler \& Pfennig 1988, Tonolla et al. 1999, Bosshard et al. 2000a). Maximum phototrophic cell concentrations in the layer vary between $10^{5}$ and $10^{6}$ cells ml ${ }^{-1}$ (Tonolla et al. 1999). In addition to these phototrophs, the chemocline layer is rich in chemolithotrophic bacteria and sulfate reducers (SRB) (Tonolla et al. 2000, 2003, Camacho et al. 2001, Peduzzi et al. 2003a). At the upper boundary of the layer, light still has 1 to $5 \%$ of its surface intensity (Fischer et al. 1996 and present study). Sulfide dif- 
fusing upwards from deeper layers and the sediment or produced by the SRB in the bacterial plume serves as electron donor for phototrophs and chemolithotrophs (Peduzzi et al. 1991, Camacho et al. 2001, DelDon et al. 2001). Although the temperature in the layer rarely exceeds $9^{\circ} \mathrm{C}$, the bacteria are physiologically highly active (Joss et al. 1994, Fischer et al. 1996, Lüthy et al. 2000, Camacho et al. 2001).

The organismic diversity of this specific microbial ecosystem has been characterized in recent years using molecular tools, revealing various closely related clones of Chromatium okenii, Amoebobacter purpureus and of sulfate-reducing bacteria (Tonolla et al. 1999, 2000, 2003, Bosshard et al. 2000b, Peduzzi et al. 2003a). A microscale sulfur cycle is assumed in the plume, as phototrophs and sulfate reducers form symbiotic aggregates (Lüthy et al. 2000, Peduzzi et al. 2003b).

Turbidity profiles obtained when routinely monitoring the lake during past decades repeatedly showed the bacterial concentration in the layer to be highly variable in space and time (Tonolla 1987 and authors' unpubl. data). Furthermore, turbidity often shows rapid temporal fluctuations, indicating the presence of moving bacterial clouds. Thus the bacterial layer must be considered as a highly dynamic system with an inhomogeneous cell distribution and possibly bioconvection. Such phenomena have been described in vitro at high cell densities (Pfennig 1962, Kessler 1985, Pedley \& Kessler 1987). In vitro experiments have furthermore demonstrated that phototrophic bacteria have a high swimming speed (Vaituzis \& Doetsch 1969, Mitchell et al. 1991) and orient themselves in light gradients as a result of phototaxis (Gest 1995, Matsuyama 1995, 1996). A few authors have observed diurnal movements of plumes of phototrophs in nature, mainly governed by the light situation in the water column (Pedros-Alio \& Sala 1990, Gervais 1997, Rodrigo et al. 1999). As internal water movements and seiches are well-known phenomena in lake physics (Münnich 1993, Imboden \& Wüest 1995), active movement can only be proven if physical displacement is excluded. Gervais (1997) ran no such controls, and the temperature profiles of Pedros-Alio \& Sala (1990) were not collected simultaneously with the cell-density samples. To compare the passive displacement of the cells by internal waves with active movement of the bacteria in the layer, we used a new experimental approach to record in situ spatial and temporal changes in cell concentration at high resolution using turbidity and temperature sensors in parallel. Continuous recording for periods of weeks during 2 summer seasons gave new insights into shortterm inhomogeneities in the bacterial community of the lake. From these data six 1 wk periods from summer and fall 1996 were selected for analysis, mainly on the basis of weather conditions (sunny, low winds) and the absence of serious technical breakdowns.

\section{MATERIALS AND METHODS}

Water chemistry. Depth profiles of temperature, $\mathrm{pH}$, redox potential, conductivity, oxygen concentration and turbidity were obtained routinely with a multisonde (HPTc: Züllig, or Aquacheck water analyzer: Perstop Analytical Environmental Instruments). These profiles were taken at the deepest site close to the automatic data-logging system for temperature and turbidity.

Light measurements. Ambient light intensity was recorded $10 \mathrm{~cm}$ below the water surface and at $11.4 \mathrm{~m}$ depth, i.e. above the bacterial plume (Li-Cor, Li193SA, Lincoln) or above the water surface with a cosine-corrected sensor (Model 68, Kontron).

Automatic recording of temperature and turbidity. Submersed light-absorption probes were built in the workshop of the institute from aluminum and Perspex. For the light source, modulated light-emitting diodes $\left(\lambda_{\max }=665 \mathrm{~nm}\right.$ with a range of 625 to $\left.700 \mathrm{~nm}\right)$ and silicon cells with electronic temperature compensation were chosen. Chlorophyll a absorption at this wavelength is negligible in the bacterial plume. The path length of $15 \mathrm{~cm}$ allowed measurement of turbidity changes from 0 to 60 FTU (formazine turbidity units). Modulated light was used to eliminate interference from sunlight. Each probe was equipped with 2 temperature sensors. One sensor recorded the temperature and the second compensated for the temperature dependency of the light-emitting diode (LED). All electronic compounds were from National Semi Conductor. A scheme of the circuit is given in Fig. 1.

Calibration of the turbidity probes was performed in the laboratory using defined suspensions of formazine prepared according to the Deutsche Einheitsverfahren (Anonymous 1992). The temperature probes were calibrated using a stirred precision water bath.

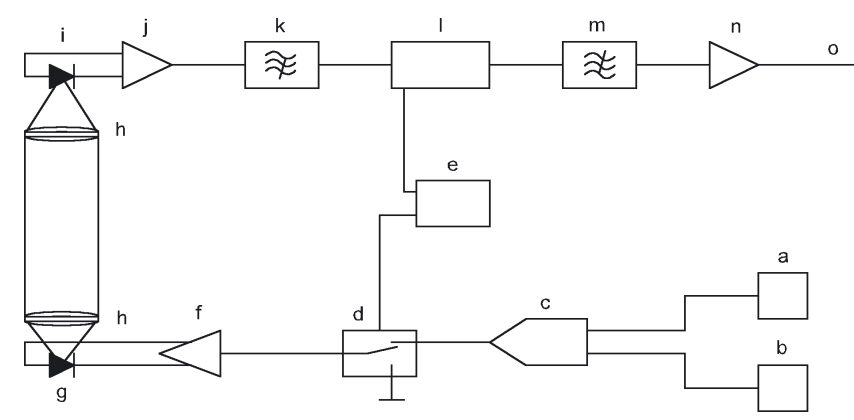

Fig. 1. Schematic overview of the electronic circuit of the turbidity-temperature sensor. a: voltage reference; b: temperature sensor; c: adjustable adding amplifier; d: modulator switch; e: oscillator; f: voltage to current converter; g: LED (light-emitting diode); h: lens; i: pin photodiode; j: pre-amplifier; k: highpass-filter; l: synchronous demodulator; $\mathrm{m}$ : lowpass filter; n: output amplifier; o: output voltage, 0 to $3 \mathrm{~V}$ 


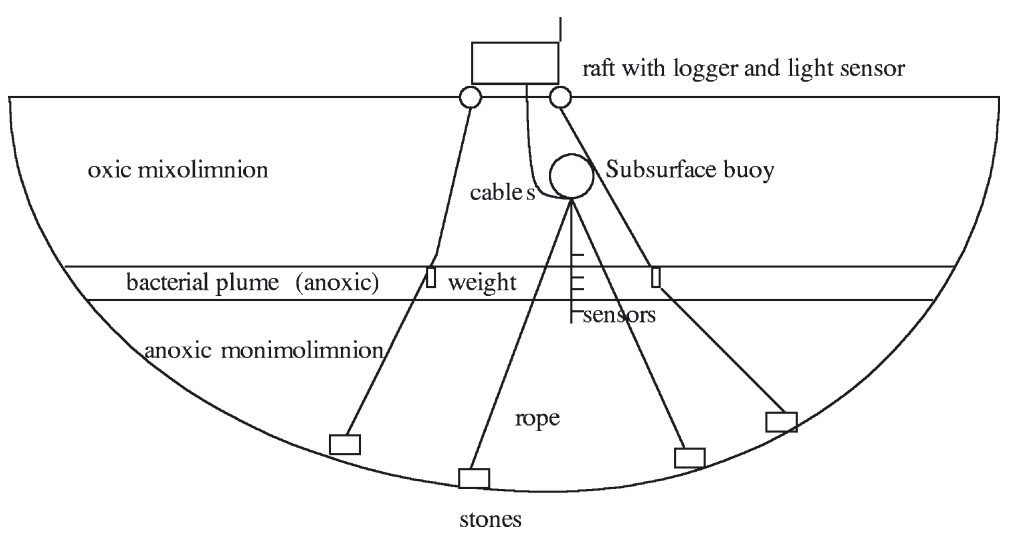

Fig. 2. Installation of the sensors in Lake Cadagno (for details see 'Materials and methods')

Installation in the lake. Turbidity and temperature signals were recorded with a data logger (Campbell Scientific). On the lake, the logger, with batteries to drive the system for up to $1 \mathrm{wk}$, was placed on a raft at the site of greatest depth. The sensors were fixed on a metal bar at the desired depth in the lake by weights and buoys; the system could be placed vertically or horizontally in the water. A subsurface buoy minimized effects of surface waves and changes in the surface level of the lake (Fig. 2). The distance between the probes was varied between 5 and $60 \mathrm{~cm}$ depending on the experiment. The sensors with the data logger were installed on the lake during part of the summer season in 1995 and 1996. Due to various specific test runs and an occasional failure of the logger or the sensors, only a few long-term runs (of at least 4 consecutive days) were finally analyzed statistically. Most of the data presented here stem from summer 1996 (July to Octo-

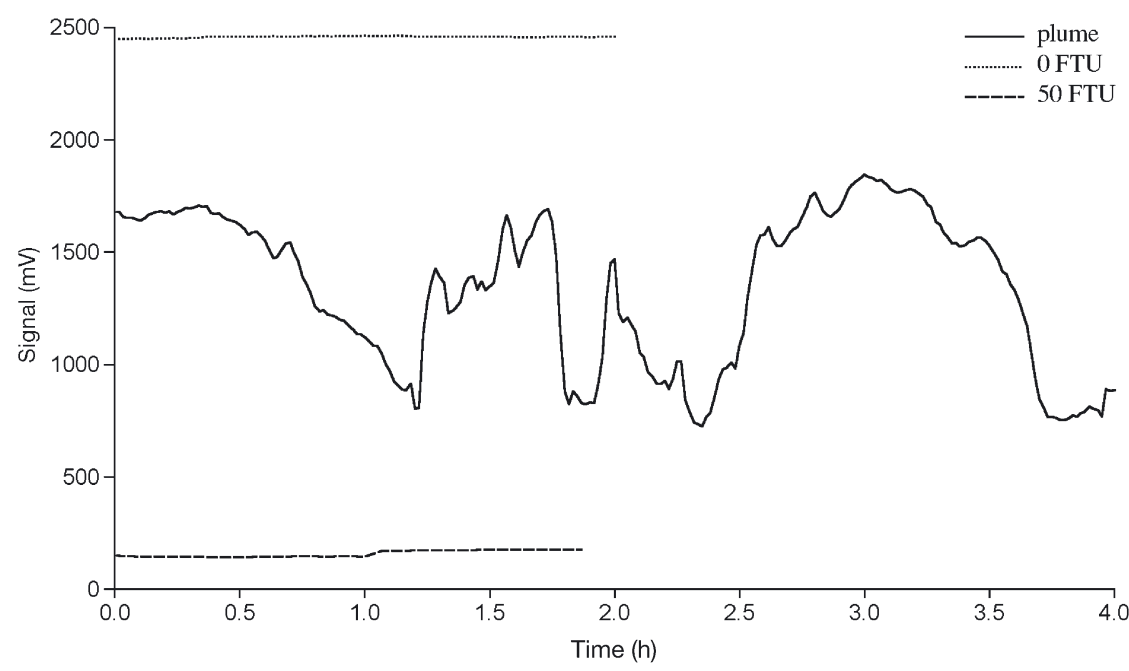

Fig. 3. Calibration of optical sensors. Time course of signal of a turbidity sensor in situ (bacterial plume in Lake Cadagno) and in calibration liquids of 0 and 50 FTU (formazine turbidity units) in the laboratory. Signal output was also calibrated in FTU units ber); the exact dates are given in the legends of Figs. 4 to 6 .

Data processing. The absorption and temperature data were recorded as $\mathrm{mV}$, digitized, stored in the logger, and regularly transferred to a computer. These raw data were transformed to ${ }^{\circ} \mathrm{C}$ and FTU values using calibration curves obtained in the laboratory. Calculations and visualization were done in Sigmaplot (Jandel Scientific) using the original time resolution and all decimals used normally by the program. Depths of the same temperature (isotherms) or the same turbidity (isoturbes) were calculated assuming linearity between 2 adjacent sensors.

\section{RESULTS}

\section{Sensor performance}

Fig. 3 gives the electric raw output of one of the sensors at 0 and 50 FTU to demonstrate the negligible electronic noise in the signal in pure water and in a homogeneous suspension. In contrast, the signal imported from an in situ measurement varies broadly within the limits of the 2 calibration curves.

Turbidity profiles and counting of microorganisms in Lake Cadagno (see e.g. Tonolla 1987, Peduzzi et al. 1991, 2003b, Joss et al. 1994, Fischer et al. 1996, Schanz et al. 1998, Tonolla et al. 1999, Lüthy et al. 2000, Camacho et al. 2001, DelDon et al. 2001) clearly show that chlorophyll a-containing organisms, while absorbing at the wavelength of the turbidity sensor, do not disturb turbidity measurements in an anoxic bacterial plume. As a consequence, the turbidity in the epilimnion above the bacterial plume was very low, usually less than 1 FTU.

\section{Fluctuations in turbidity and temperature at a single point}

To determine the optimal measurement interval, data were sampled at intervals of 2, 10 and $60 \mathrm{~s}$ and compared with higher sampling intervals. With a sampling interval of $5 \mathrm{~min}$, many of the minor inhomogeneities seen at a high resolution of 2 and $10 \mathrm{~s}$ measurement frequency were eliminated; however, the major mass movements of the layer 


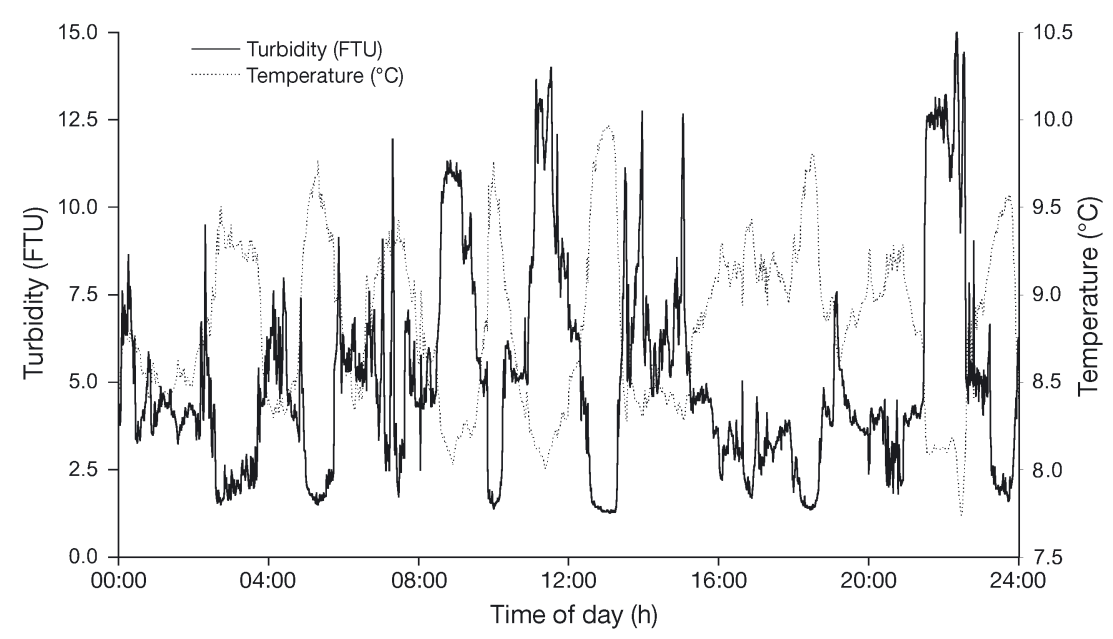

Fig. 4. Time course of temperature and turbidity recorded by single sensor in Cadagno Lake at $12.5 \mathrm{~m}$ depth over $1 \mathrm{~d}$ (4 October 1996)

\section{Horizontal inhomogeneities}

We installed 4 sensors horizontally on a metal bar at the same depth in the bacterial layer. In 3 experiments, the gap between each sensor was set at 5,25 or $60 \mathrm{~cm}$, resulting in a distance between the first and last sensor of 15, 75, and $180 \mathrm{~cm}$, respectively.

When the sensors were spaced at $5 \mathrm{~cm}$ intervals, the signals from the 4 sensors were practically identical when sampling intervals of 1 to $3 \mathrm{~min}$ were used. All turbidity peaks appeared simultaneously, with the same amplitude. At a higher sampling rate of $5 \mathrm{~s}$, small differences of maximally 0.5 FTU at a level of 8 FTU were observed combined with irregular small fluctuations (data not shown). However, these deviations were larger than the electronic noise of the

were still clearly observed. Therefore, measurement intervals of 1 min were used routinely to obtain maximum information on the movement in the bacterial layer during long-term measurement periods. Fig. 4 gives the turbidity and temperature tracks at $12.5 \mathrm{~m}$ depth over a $24 \mathrm{~h}$ period. Roughly, an oscillation frequency of 1 per $2 \mathrm{~h}$ is visible, and the temperature curve often appears as a mirror-image of turbidity. The measurement site at $12.5 \mathrm{~m}$ was in the upper part of the bacterial plume; thus when the water mass moved downwards, temperature increased and the sensor was located above the bacterial layer with a low turbidity value. A turbidity of 8 FTU was arbitrarily selected as both the upper and lower boundaries of the bacterial plume. When the data of turbidity and temperature from a single sensor (as in Fig. 4) were analyzed for a $1 \mathrm{~d}$ period, the temperature range between the two 8 FTU limits varied between 7.73 and $8.42^{\circ} \mathrm{C}$ (176 values) with an average of $8.15^{\circ} \mathrm{C}$ and a standard deviation of $0.12^{\circ} \mathrm{C}$. These data indicate that there was a small temperature gradient within the bacterial layer and that the bacteria remained within a relatively narrow temperature range. Large temperature fluctuations at a specific depth result from internal waves or seiches. When changes in temperature and turbidity correlate, the bacteria are transported passively in an advective mass flow. In large lakes, seiches regularly occur due to wind forces, but for morphometric reasons such oscillations are of much lower frequency than those observed in Lake Cadagno. Seiches may be absent from small lakes such as Lake Arcas-2 (Rodrigo et al. 1999). Such rapid vertical movements of the bacterial layer, which frequently result in changes of up to 8 FTU within 1 min, are critical to the accuracy of chemical and biological profiles when sampling with rather slow conventional methods. sensors in pure water or in inorganic calibration solution (Fig. 3). Therefore, these fluctuations reflect small local inhomogeneities in cell density and indicate turbidity changes caused by the formation and displacement of bacterial clouds over short time periods and at the same site (Mitchell et al. 1996). For the probes installed at $25 \mathrm{~cm}$ intervals, the major turbidity peaks shifted little over time. This changed dramatically when the sensors were positioned $60 \mathrm{~cm}$ apart (Fig. 5). Internal horizontal waves became visible as time lags in rapid turbidity changes between the sensors. Such turbidity changes at a particular depth are due to horizontal movements of a turbidity gradient. Since these waves were also present in the temperature changes, the bacterial population was transported vertically, as a whole, in a unit of water mass. Such waves were observed frequently, up to 10 times a day (see also Fig. 4). The turbidity peaks always followed the sequence of the sensors in the lake. The time for a turbidity peak to travel from the first to the last sensor varied between 6 and $20 \mathrm{~min}$. As it was not possible to determine the relative direction of the waves nor the angular orientation of the turbidity sensors, the minimal velocity of the waves derived from these data is about 9 to $30 \mathrm{~cm} \mathrm{~min}^{-1}$. In the experiment illustrated in Fig. 5, the sensors were positioned at the lower edge of the plume at the beginning of the experiment, as indicated by both low temperature and low turbidity. Due to an internal wave, the water with bacteria was forced downwards, and both temperature and turbidity increased at the site of the sensors, first at Sensor 1 and finally at Sensor 4. Shortly afterwards, the temperature reached a maximum, while turbidity dropped again, indicating that the sensors were now situated above the bacterial plume; 1 $\mathrm{h}$ later, turbidity increased and temperature decreased again, but in the opposite direction along the sensor row. 


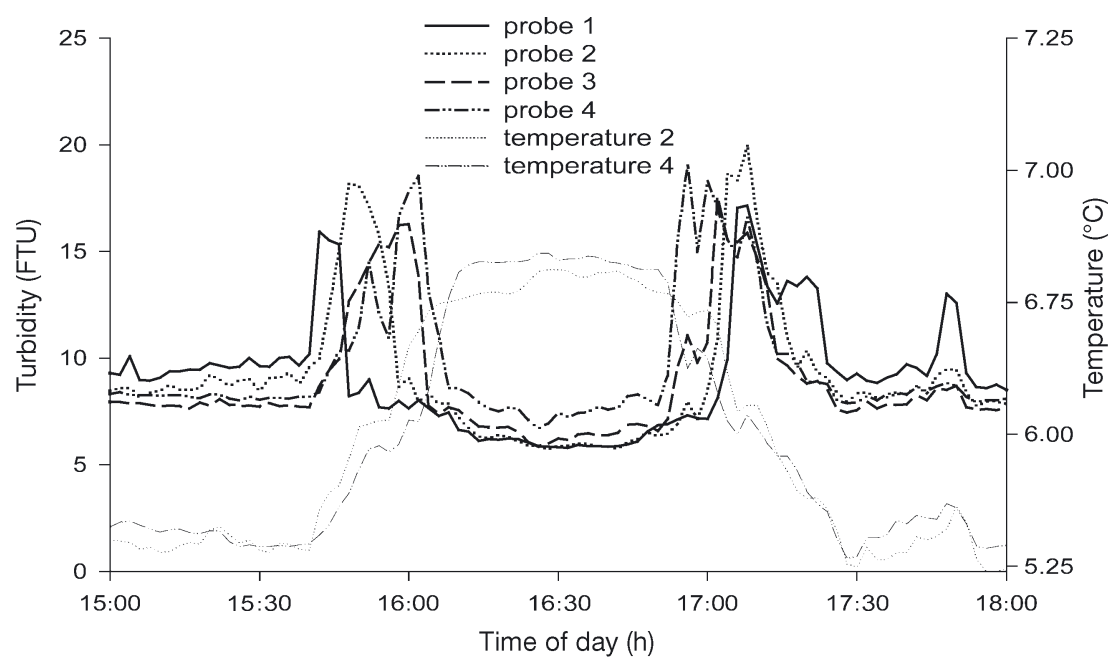

Fig. 5. Time course of temperature and turbidity recorded by 4 sensors placed horizontally with equidistant spacing of $60 \mathrm{~cm}$ situated at $13.8 \mathrm{~m}$ depth for $3 \mathrm{~h}$. For temperature, only data for Sensors 2 and 4 are shown (12 July 1996, sunny day, slight wind)

\section{Vertical inhomogeneities}

Vertical inhomogeneities were studied using 8 or 9 sensors placed vertically on a metal bar at distances of 25 or $30 \mathrm{~cm}$ at a depth that included the whole bacterial layer plus part of the water above and below this layer (Fig. 2). The turbidity changes over a period of $5 \mathrm{~d}$ from 27 September to 2 October 1996 indicate that the upper part of the bacterial layer was sharply and distinctly separated from the low-turbidity oxic epilimnion (or upper part of the water column) (Fig. 6). These conditions resulted in a definite barrier for the anaerobic phototrophic bacteria. In contrast, the lower boundary of the layer was diffuse due to the continuously sedimenting biomass, mainly from the bacterial plume down to the bottom of the lake, a situation also seen in molecular studies (Bosshard et al. 2000b). The pattern of the bacterial density changed continuously, both the width of the bacterial layer and its maximum turbidity value. Frequency analysis revealed 3 main time periods for the physically induced oscillations: 2.5 and $4.9 \mathrm{~h}$ in the upper part of the layer and $9.8 \mathrm{~h}$ in the lower part. These values varied slightly over the season, probably influenced by changes in the level of the lake surface and the depth of the water column. During long periods of stable weather conditions, bright sun and low winds, further oscillations with a period of close to $12 \mathrm{~h}$ were detected, suggesting a diurnal cycle coupled to the day/night regime.

To separate the passive mass transport of bacteria and other suspended particles from active movement of live bacteria, 2 approaches were taken. Isolines for turbidity and temperature were calculated for a period of $5 \mathrm{~d}$, averaged to a $24 \mathrm{~h}$ day/night period, and smoothed by a

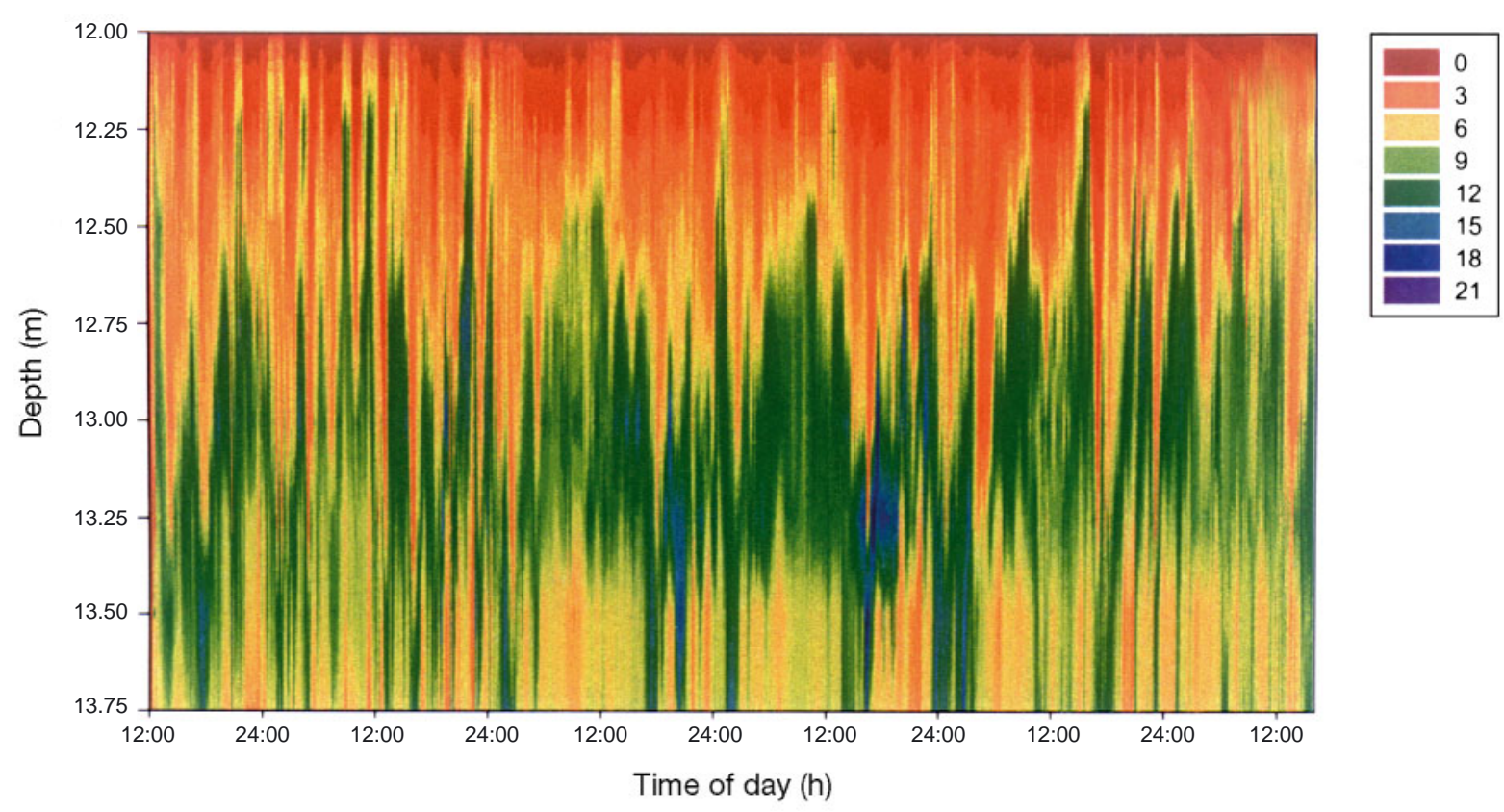

Fig. 6. Time-depth 3D plot of turbidity (FTU, color-coded) recorded by 9 sensors placed vertically with equidistant spacing of $25 \mathrm{~cm}$ for $5 \mathrm{~d}$ (27 September to 2 October 1996) 


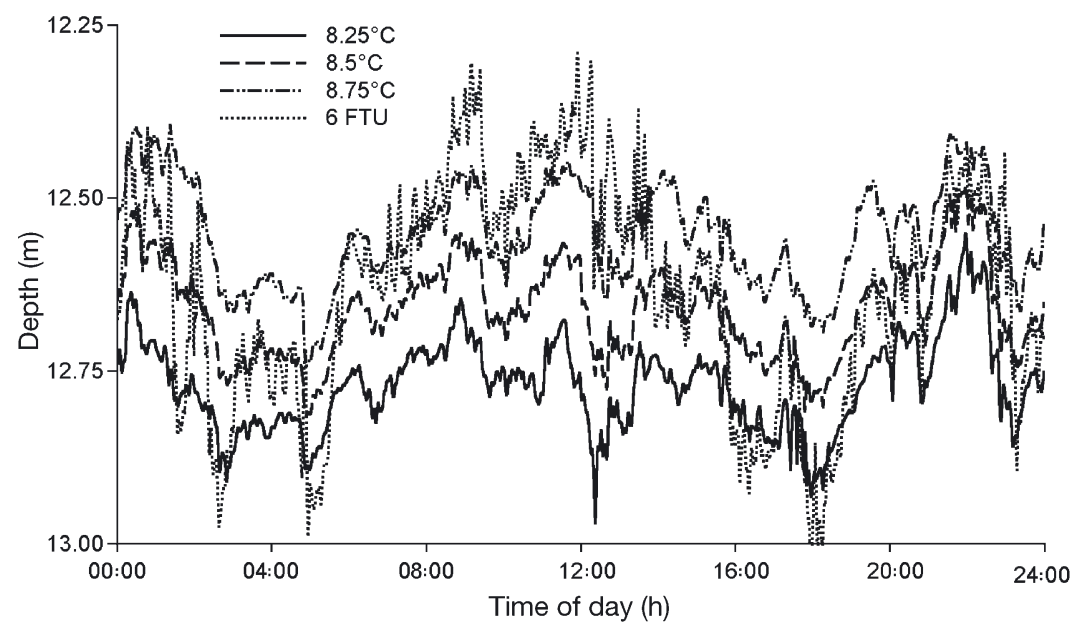

Fig. 7. Daily averaged isolines of turbidity and temperature over $5 \mathrm{~d}$ period, moving average (3 values). Data from Fig. 6 (27 September to 2 October 1996)

moving average (Fig. 7). Active movement of the bacterial population can be assumed when turbidity is displaced compared to the temperature as an indicator of moving water mass. The turbidity value of 6 FTU was compared with the closest isotherms, 8.25, 8.5 and $8.75^{\circ} \mathrm{C}$ (Fig. 7). During the earliest hours of the day, to 05:00 h, a turbidity value of 6 FTU was recorded for water of about 8.25 to $8.5^{\circ} \mathrm{C}$, then between 06:00 and 09:00 $\mathrm{h}$, the 6 FTU turbidity isoline moved upwards and was associated with higher-temperature water. In the afternoon between 13:00 and 14:00 $\mathrm{h}$, a downward movement was observed, followed by some small upward oscillations toward evening (Fig. 7). This different behavior of the turbidity and temperature isolines was independent of depth within the plume: even the 9 FTU line at the bottom of the plume showed a similar dis- placement (data not shown). The steep light gradient within the plume indicates that light intensity must be extremely low at this site (Fischer et al. 1996). Interestingly, active movement was not regularly observed during all periods of the year, e.g. it was more pronounced at the end of September 1996 than in the previous month.

A plot of mean turbidity against temperature for the averaged time periods 00:00 to 06.00 h, 06:00 to $12: 00 \mathrm{~h}, 12: 00$ to $18: 00 \mathrm{~h}$, and 18:00 to $24: 00 \mathrm{~h}$, during the same $5 \mathrm{~d}$ period demonstrates that the cells moved to a colder temperature $(=$ greater depth) during the period 00:00 to 06:00 h. Fig. 8 gives an example for $12.5 \mathrm{~m}$ depth, which was in the upper third of the layer. Although the standard deviation is large, it is obvious that maximum turbidity was associated with regions of higher temperature during the day and colder regions at night. This pattern was apparent over the whole width of the bacterial layer, even at $13.5 \mathrm{~m}$, which was close to the lower boundary of the plume (Fig. 6). A similar plot, using data from the end of August (1 mo before the data in Fig. 8) showed no difference between the 4 time periods, indicating that active movement of the bacterial plume at this time was negligible.

Data collected in August, i.e. 1 mo before the data presented here (Figs. 4 \& 6 to 8 ) were analyzed for further indications of active movement of the bacteria in the bacterial layer. Various mathematical algorithms such as autoregression and geostatistics were used to correlate temperature data with turbidity data (Gerss 1998). However, these yielded no further information on the active movement of the bacteria than the more empirical approach described above.

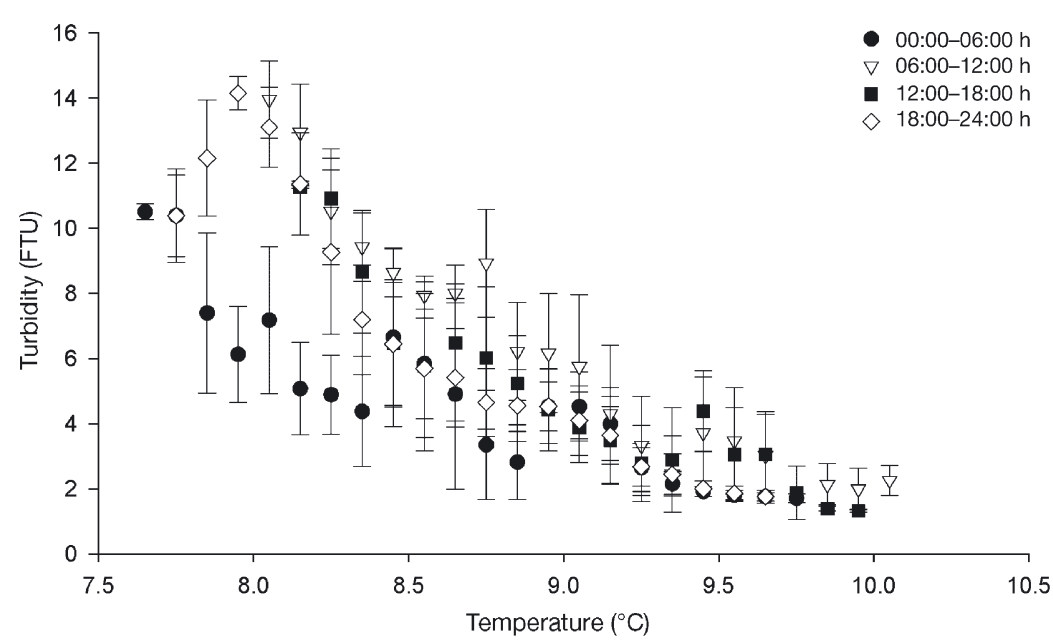

Fig. 8. Turbidity-temperature plot for $12.5 \mathrm{~m}$ depth, temperature in steps of $0.1^{\circ} \mathrm{C}$ with standard deviation. Data from Fig. 6 (27 September to 2 October 1996)

\section{DISCUSSION}

This paper describes periodic vertical displacements of a dense layer dominated by phototrophic bacteria in a meromictic lake. The oscillations observed in temperature profiles suggest that large water masses are displaced by physically induced internal waves. Thus the main movements of the bacterial layer observed are passive displacements. The local weather, mainly wind speed and wind direction, is the driving force in the magnitude and direction of these waves. The amplitude of the vertical displacement increased at higher wind speeds to a maximum upward displacement in October 1996 of $1.4 \mathrm{~m}$ within $30 \mathrm{~min}$ (data not shown). It is 
thus difficult to prove a diurnal active movement of the bacteria, which is superimposed upon these physical waves in the Cadagno lake system. However, by correcting the main turbidity movements by the movements of the water masses, it was possible to demonstrate an independent movement.

Active movement and phototactic behavior of single phototrophic organisms is well documented, and the movement of whole populations of phototrophs in a natural environment has also been suggested. A dynamic upper boundary of the bacterial plume, consisting mainly of Amoebobacter purpureus, has been observed in Lake Mahoney (Overmann et al. 1991, 1994, Overmann \& Pfennig 1992). Upward movement of 35 to $43 \mathrm{~cm}$ during the day by Chromatium minus and $C$. weissei has been suggested in small Spanish lakes (Pedros-Alio \& Sala 1990, Rodrigo et al. 1999) and by C. okenii in the Schlachtensee (Gervais 1997). In all cases, sampling intervals were fairly long, 3 to 5 $\mathrm{h}$, a time interval that would not allow the identification of biological movements in Lake Cadagno. Furthermore, only Rodrigo et al. (1999) ran controls for possible physical movements in the water column.

The mechanisms of vertical movement by Amoebobacter sp. are density changes and aggregation (Overmann et al. 1994); in contrast, Chromatium sp. is flagellated and able to swim actively. It is thus not surprising that for Amoebobacter sp. no vertical movement was detected within a period of hours (Pedros-Alio \& Sala 1990). In laboratory experiments, a swimming speed of $46 \mu \mathrm{m} \mathrm{s}^{-1}$ was observed at $20^{\circ} \mathrm{C}$ for C. okenii (Vaituzis \& Doetsch 1969), while for C. minus speeds of up to $120 \mu \mathrm{m} \mathrm{s}^{-1}$ for periods of up to $20 \mathrm{~s}$ duration at low light have been recorded (Mitchell et al. 1991). In Lake Cadagno, both types of phototrophic bacteria, Amoebobacter sp. and Chromatium sp., are present, and the ratio between these populations in the plume changes as a function of season as well as between years (Tonolla 1987, Bosshard et al. 2000b, Tonolla et al. 2000). Although the data of Bosshard et al. (2000b) are not for the same year as those in the present study, it is very probable that a population change explains the absence of active movement at the end of August and the presence of active movement at the end of September. The maximum total counts in summer 1996 were around $1.1 \times 10^{7} \mathrm{ml}^{-1}$; towards the end of September the number had dropped to $3 \times$ $10^{6} \mathrm{ml}^{-1}$. At the beginning of our study, C. okenii dominated the phototrophs, with $10^{5} \mathrm{ml}^{-1}$ in mid-June, but dropped to $10^{2}$ at the end of September. In contrast, Lamprocystis sp. started with $5 \times 10^{4} \mathrm{ml}^{-1}$ in June and reached $3 \times 10^{5} \mathrm{ml}^{-1}$ at the end of September $(\mathrm{M}$. Tonolla unpubl.).

The turbidity signal is determined by the number of particles per volume as well as by their size and shape, and does not distinguish between species. The rapid changes in signal size over short time periods at a particular site in the lake could not have been caused by bacterial growth. Within a $4 \mathrm{~h}$ period, no increase in cell protein was found in situ in closed vessels (Fischer et al. 1996). Small changes in volume or density of cells occurred slowly (over a period of hours) in the daily cycle in Lake Ciso (Spain) due to accumulation or consumption of elemental sulfur and carbon polymers (van Gemerden et al. 1985); such metabolic processes may also reflect changes in the turbidity signal. Thus, practically all rapid dynamics of the turbidity signal must originate from actual displacements of suspended bacterial cells.

We used different approaches to demonstrate that at least part of the bacterial movement is independent of the physical oscillations observed in temperature fluctuations. Besides active swimming of single cells as a consequence of photo- and chemotaxis or changes in the buoyant density of the cell, a mass flow-driven displacement in the form of bioconvection (Pfennig 1962) may also contribute to a biologically determined rapid displacement. For bioconvection to occur, a minimal cell concentration is necessary; $>10^{5}$ to $10^{6} \mathrm{cells} \mathrm{ml}^{-1}$ has been suggested (Levandowsky et al. 1975, Kessler 1985). For $5 \mu \mathrm{m}$ diameter particles with a density $\rho$ of $1.2 \mathrm{~g} \mathrm{~cm}^{-3}$, Wüest (1994) calculated that a minimal particle concentration of $10^{6} \mathrm{ml}^{-1}$ would be necessary for bioconvection to start. Such numbers are often reached in the plume in Lake Cadagno. A decade ago, both temperature and conductivity were found to be practically constant within the bacterial layer (Israng 1992, Wüest 1994). In the present study, a small temperature gradient was observed within the layer. Long-term observations (M. Tonolla unpubl.) suggest that cell concentrations in the plume have dropped compared to 10-15 yr ago. Comparison of the earlier and present observations suggests that active bacterial swimming motion and bioconvection may have destroyed the density gradient in the bacterial layer, leading to equilibrium in the bacterial plume and thus increasing the possibility of bioconvection. The diminished biomass now present may no longer be able to overcome the density and temperature gradients by bioconvection, and bioconvection may today play only a minor and local role.

The bacterial layer is highly inhomogeneous. Its thickness varies with time and bacterial clouds form within the plume. The average distance between the upper and lower 8 FTU isoline (taken as an arbitrary measure of the thickness of the layer at the end of August) amounts to $0.80 \mathrm{~m}$ with a standard deviation of $0.23 \mathrm{~m}$. FTU numbers and plume dimensions can change within minutes, a phenomenon that cannot be explained by active movement. In our time series, the 
amplitudes of neighboring isotherms differing by $0.25^{\circ} \mathrm{C}$ were not identical, and the beginning and end of extreme changes did not coincide exactly throughout the profile. These differences arose from horizontal waves that differ in the upper and the lower parts of the bacterial layer. Horizontal waves transporting bacteria could explain short-term density changes in the plume.

A successful demonstration of active cell movement in the context of the large physical background of this alpine lake is also dependent on the structure of the bacterial population in the plume. Chromatium okenii dominated in the summer months, and was replaced by Amoebobacter purpureus and Lamprocystis sp. populations in late autumn and winter in the years 1996 and 1998 (Bosshard et al. 2000b, M. Tonolla unpubl.). Active displacement of the upper boundary at the end of September 1996 was $\sim 25 \mathrm{~cm}$ within $\sim 5 \mathrm{~h}$. Traveling directly towards the light at an assumed average swimming speed of $20 \mu \mathrm{m} \mathrm{s}^{-1}, C$. okenii would need just $20 \mathrm{~min}$ for a vertical movement of $24 \mathrm{~cm}$. Even with random movement, this motility would be sufficient for upward translocation of the plume by 25 to $30 \mathrm{~cm}$ within a few hours.

The seasonal light regime as well as the light distribution in the bacterial plume is extremely important for phototactic behavior and the photosynthetic production. Within the bacterial plume, light intensity changed by a factor of 100 from the surface to below the plume (see also Fischer et al. 1996, Schanz et al. 1998). During the present study, on average, $2.2 \%$ of the light that entered the water reached the plume surface. On a bright sunny day the light intensity just below the water surface reached $2000 \mu \mathrm{mol}$ quanta $\mathrm{s}^{-1} \mathrm{~m}^{-2}$, while $34 \mu \mathrm{mol}$ quanta $\mathrm{s}^{-1} \mathrm{~m}^{-2}$ were recorded just above the layer. Matsuyama $(1995,1996)$ reported $10 \mu \mathrm{mol}$ quanta $\mathrm{s}^{-1} \mathrm{~m}^{-2}$ at the upper boundary of the bacterial layer in a Japanese meromictic lake. Sulfur globules observed in Chromatium sp. cells in the Japanese lake suggest that this light intensity still allowed high physiological activity. At lower light intensities, cells moved upwards. In Lake Cadagno, C. okenii cells are rich in sulfur globules, and the active mass movement of bacteria we observed was independent of the bacteria's position in the bacterial layer, although it would be expected from the steep light gradient and the conversely oriented sulfide gradient that photo- and chemotactical behavior of the bacteria would differ in the lower and top parts of the layer. Differing physiologies in the population within a depth profile has been shown earlier (Joss et al. 1994, Fischer et al. 1996). Schanz et al. (1998) give evidence that not only the maximum rate of photosynthesis $\left(P_{\max }\right)$, but also the light intensity at which $P_{\max }$ is reached, depend on the irradiance at the site of the cells. Increased light inten- sities above $0.03 \mathrm{E} \mathrm{m}^{-2} \mathrm{~h}^{-1}$ inhibit photosynthesis. That these phototrophic bacteria sense very low light intensities is supported by the rapid rate of pigment synthesis (Fischer et al. 1996) as well as their active upward displacement in the early morning before sunrise (present paper).

Beside phototaxis, chemotaxis towards hydrogen sulfide or other reduced sulfur compounds (as essential electron donors) and away from oxygen (as a toxic environmental factor) may be further determinants of cell distribution. Online sulfide and oxygen records could provide additional information on the in situ role of chemotaxis in daily bacterial movements. Furthermore, the small-scale vertical inhomogeneities found and the formation of bacterial clouds and patches may be due to locally variable motility of the bacteria or the result of interspecific communication. Patchiness has been discussed for phytoplankton by Platt \& Denman (1980) and has even been demonstrated on the 10 to $100 \mu \mathrm{m}$ scale for bacteria (Kembs et al. 1998, Long \& Azam 2001); it would be of great interest to apply these high-resolution techniques to plumes of meromictic lakes.

Acknowledgements. We are much indebted to AME Subject Editor Dr. Robert Sanders, for his comments and his help in clarifying the English text.

\section{LITERATURE CITED}

Anonymous (1992) Deutsches Einheitsverfahren zur Wasser-, Abwasser- und Schlamm-Untersuchung. Verlag Chemie, Weinheim. Bestimmung der Trübung nach ISO 7027:1990, method $\mathrm{C} 2$

Bosshard PP, Santini Y, Grüter D, Stettler R, Bachofen R (2000a) Bacterial diversity and community composition in the chemocline of the meromictic alpine Lake Cadagno as revealed by $16 \mathrm{~S}$ rDNA analysis. FEMS Microbiol Ecol 31: 173-182

Bosshard PP, Stettler R, Bachofen R (2000b) Seasonal and spatial community dynamics in the meromictic Lake Cadagno. Arch Microbiol 174:168-174

Camacho A, Erez J, Chicote A, Florin M, Squires MM, Lehmann C, Bachofen R (2001) Microbial microstratification, inorganic carbon photoassimilation and dark carbon fixation at the chemocline of the meromictic Lake Cadagno (Switzerland) and its relevance to the food web. Aquat Sci 63:91-106

DelDon C, Hanselmann KW, Peduzzi R, Bachofen R (2001) The meromictic lake Cadagno: orographical and biochemical description. Aquat Sci 63:70-90

Düggeli M (1919) Die Schwefelbakterien. Neujahrsbl Naturforsch Ges Zürich, 121. Beer \& Cie, Zurich

Düggeli M (1924) Hydrobiologische Untersuchungen im Pioragebiet: bakteriologische Untersuchungen am Ritomsee. Schweiz Z Hydrol 2:62-205

Eichler B, Pfennig N (1988) A new purple sulfur bacterium from stratified freshwater lakes, Amoebobacter purpureus sp. nov. Arch Microbiol 149:395-400

Fischer C, Wiggli M, Schanz F, Hanselmann KW, Bachofen R 
(1996) Light environment and synthesis of bacteriochlorophyll by populations of Chromatium okenii in natural environments. FEMS Microbiol Ecol 21:1-9

Gerss J (1998) Statistische Analyse von Raum-Zeit-Daten aus der Limnologie: Untersuchung aktiver Vertikalbewegungen von Schwefelpurpurbakterien in ihrer natürlichen Umgebung. Ms thesis, University of Dortmund

Gervais F (1997) Diel vertical migration of Cryptomonas and Chromatium in the deep chlorophyll maximum of an eutrophic lake. J Plankton Res 19:533-550

Gest H (1995) Phototaxis and other sensory phenomena in purple photosynthetic bacteria. FEMS Microbiol Rev 16: 287-294

Imboden DM, Wüest A (1995) Mixing mechanisms in lakes. In: Lerman A, Imboden D, Gat JR (eds) Physics and chemistry of lakes. Springer-Verlag, Heidelberg, p 83-138

Israng R (1992) Bewegungsdynamik einer Bakterienpopulation in einem meromiktischen Bergsee. Ms thesis, University of Zurich

Joss A, Mez K, Känel B, Hanselmann KW, Bachofen R (1994) Measurement of fluorescence kinetics of phototrophic bacteria in the natural environment. J Plant Physiol 144: 333-338

Kembs C, Juhl AR, Strickler JR (1998) Nanoscale patchiness of bacteria in lake water studied with the spatial information preservation method. Limnol Oceanogr 43:307-314

Kessler J (1985) Hydrodynamic focusing of motile algal cells. Nature 313:218-220

Levandowsky M, Childress WS, Spiegel EA, Hunter SH (1975) A mathematical model of pattern formation by swimming microorganisms. J Protozool 22:296-306

Long RA, Azam F (2001) Microscale patchiness of bacterioplankton assemblage richness in seawater. Aquat Microb Ecol 26:102-113

Lüthy L, Fritz M, Bachofen R (2000) In situ determination of sulfide turnover rates in a meromictic alpine lake. Appl Environ Microbiol 66:712-717

Matsuyama M (1995) Upward movement of Chromatium sp. in the $\mathrm{H}_{2} \mathrm{~S}$ layer of Lake Kaiike causing a bloom at its upper boundary. Jpn J Limnol 56:205-209

Matsuyama M (1996) Further comments on upward movement of Chromatium sp. in the $\mathrm{H}_{2} \mathrm{~S}$ layer of Lake Kaiike. Jpn J Limnol 57:179-182

Mitchell JG, Martinez-Alonso M, Lalucat J, Esteve I, Brown S (1991) Velocity changes, long runs, and reversals in the Chromatium minus swimming response. J Bacteriol 173: 997-1003

Mitchell JG, Pearson L, Dillon S (1996) Clustering of marine bacteria in seawater enrichments. Appl Environ Microbiol 62:3716-3721

Münnich M (1993) On the influence of bottom topography on the vertical structure of internal seiches. PhD thesis, University of Heidelberg

Overmann J, Pfennig N (1992) Buoyancy regulation and aggregate formation in Amoebobacter purpureus from Mahoney lake. FEMS Microbiol Ecol 101:67-79

Overmann J, Beatty T, Hall KJ, Pfennig N, Northcote TG (1991) Characterization of a dense, purple sulfur bacterial layer in a meromictic lake. Limnol Oceanogr 36:846-859

Overmann J, Beatty JT, Hall KJ (1994) Photosynthetic activity

Editorial responsibility: Robert Sanders,

Philadelphia, Pennsylvania, USA and population dynamics of Amoebobacter purpureus in a meromictic saline lake. FEMS Microbiol Ecol 15:309-320

Pedley TJ, Kessler J (1987) The orientation of spheroidal microorganisms swimming in a flow field. Proc R Soc Lond B 231:47-70

Pedros-Alio C, Sala MM (1990) Microdistribution and diel vertical migration of flagellated vs gas-vacuolate purple sulfur bacteria in a stratified water body. Limnol Oceanogr 35:1637-1644

Peduzzi R, Tonolla M, Demarta A, DelDon C, Hanselmann K, Bachofen R (1991) Rôle de Chromatium okenii dans le métabolisme d'un lac méromictique (L. Cadagno) In: Vernet JP (ed) Hommage à F. A. Forel. Morges, p 183-189

Peduzzi S, Tonolla M, Hahn D (2003a) Vertical distribution of sulfate-reducing bacteria in the chemocline of Lake Cadagno, Switzerland, over an annual cycle. Aquat Microbial Ecol 30:295-302

Peduzzi S, Tonolla M, Hahn D (2003b) Isolation and characterization of aggregate forming sulfate-reducing and purple sulfur bacteria from the chemocline of meromictic Lake Cadagno. FEMS Microbiol Ecol 45:29-37

Pfennig N (1962) Beobachtungen über das Schwärmen von Chromatium okenii. Arch Microbiol 42:90-95

Platt T, Denman K (1980) Patchiness in phytoplankton distribution. In: Morris I (ed) The physiological ecology of phytoplankton. Blackwell, Oxford, p 413-431

Rodrigo MA, Camacho A, Vicente E, Miracle MR (1999) Microstratified vertical distribution and migration of phototrophic microorganisms during a diel cycle in Lake Arcas-2 (Spain). Arch Hydrobiol 145:492-512

Schanz F, Fischer-Romero C, Bachofen R (1998) Photosynthetic production and photoadaptation of phototrophic sulfur bacteria in Lake Cadagno (Switzerland). Limnol Oceanogr 43:1262-1269

Tonolla M (1987) Ueber das photochemotaktische Verhalten von Purpurschwefelbakterien in ihrer natürlichen Umgebung. Ms thesis, University of Zurich

Tonolla M, Demarta A, Peduzzi R, Hahn D (1999) In situ analysis of phototrophic sulfur bacteria in the chemocline of meromictic Lake Cadagno (Switzerland). Appl Environ Microbiol 65:1325-1330

Tonolla M, Demarta A, Peduzzi S, Hahn D, Peduzzi R (2000) In situ analysis of sulfate-reducing bacteria related to Desulfocapsa thiozymogenes in the chemocline of meromictic Lake Cadagno (Switzerland). Appl Environ Microbiol 66:820-824

Tonolla M, Peduzzi S, Hahn D, Peduzzi R (2003) Spatio-temporal distribution of phototrophic sulfur bacteria related to Desulfocapsa thiozymogenes in the chemocline of meromictic Lake Cadagno (Switzerland). FEMS Microbiol Ecol 43:89-98

Vaituzis Z, Doetsch RN (1969) Motility tracks: technique for quantitative study of bacterial movement. Appl Microbiol 17:584-588

van Gemerden H, Montesinos E, Mas J, Guerrero R (1985) Diel cycle of metabolism of phototrophic purple sulfur bacteria in Lake Ciso (Spain). Limnol Oceanogr 30: 932-943

Wüest A (1994) Interaktion in Seen: die Biologie als Quelle dominanter physikalischer Kräfte. Limnologica 24:93-104

Submitted: April 20, 2003; Accepted: October 16, 2003

Proofs received from author(s): April 15, 2004 